\title{
LABORATORY STUDY ON LOW-TEMPERATURE COAL SPONTANEOUS COMBUSTION IN THE AIR OF REDUCED OXYGEN AND LOW METHANE CONCENTRATION
}

\author{
Gang Wang, Jun Xie, Sheng Xue, Haiyang Wang
}

Original scientific paper

Laboratory tests were conducted to study coal spontaneous combustion at low-temperature $\left(30 \div 200{ }^{\circ} \mathrm{C}\right)$ in the air of reduced oxygen $(10 \div 21 \%)$ and low methane concentrations $(0 \div 3 \%)$. The production of carbon monoxide in coal spontaneous combustion was analysed. The test results show that both oxygen and methane concentrations affect coal spontaneous combustion. At given oxygen concentration the methane concentration in air had a positive impact on coal spontaneous combustion and the impact increased with methane concentration. This impact was weakened and diminished with the rise of temperature. The initial carbon dioxide temperate at which carbon monoxide started to appear increased with the reduction of oxygen concentration in the air and the increase was somewhat negated by the presence of increased methane concentration in air. However, as the oxygen concentration reduced to a certain value, methane concentration showed little or no influence on coal spontaneous combustion. The low temperature sorption characteristics of oxygen and methane by coal were applied to explain the results. The findings in this study are particularly useful in the prediction and control of coal spontaneous combustion in gassy coal mines.

Keywords: coal mine; coal spontaneous combustion; low temperature; low methane concentration; oxygen concentration

\section{Laboratorijska analiza spontanog izgaranja ugljena na niskoj temperaturi u zraku s reduciranim kisikom i niskom koncentracijom metana}

Izvorni znanstveni članak

Provedena su laboratorijska ispitivanju u svrhu proučavanja spontanog izgaranja ugljena na niskoj temperaturi $\left(30 \div 200{ }^{\circ} \mathrm{C}\right) \mathrm{u}$ zraku $\mathrm{s}$ reduciranim kisikom $(10 \div 21 \%)$ i niskim koncentracijama metana $(0 \div 3 \%)$. Analiziralo se stvaranje ugljičnog monoksida kod spontanog izgaranja ugljena. Rezultati ispitivanja pokazuju da i koncentracije kisika i metana djeluju na spontano izgaranje ugljena. Pri datoj koncentraciji kisika koncentracija metana u zraku je imala pozitivan učinak na spontano izgaranje ugljena, a učinak se povećao s koncentracijom metana. Taj je učinak oslabio i smanjio se porastom temperature. Početna je temperature ugljičnog dioksida, kod koje se ugljični monoksid počeo javljati, porasla smanjenjem koncentracije kisika u zraku, a porast je donekle smanjen povećanjem koncentracije metana u zraku. Međutim, kako se koncentracija kisika smanjivala do određene vrijednosti, koncentracija metana je pokazivala malo ili nikakvog utjecaja na spontano izgaranje ugljena. Uzete su u obzir karakteristike ugljena kod niske temperature sorpcije kisika i metana kako bi se objasnili rezultati. Dobiveni rezultati su od posebne koristi u predviđanju i praćenju spontanog izgaranja ugljena u plinovitim ugljenokopima.

Ključne riječi: koncentracija kisika; niska koncentracija metana; niska temperatura; spontano izgaranje ugljena; ugljenokop

\section{Introduction}

Spontaneous combustion of coal is a serious hazard in coal-related industries such as coal mining, coal transportation and coal storage. If not properly controlled, it can lead to the emission of toxic and explosive gases together with propagation to open fire, and it can become a potential ignition source for an explosion if exposed to a flammable mixture of gas. It is well known that the physical and chemical interaction between coal and molecular oxygen $\left(\mathrm{O}_{2}\right)$, or coal oxidation, is the major reason responsible for spontaneous combustion of coal. Coal oxidation is a complicated process involving a number of phenomena such as the release of heat and the emission of gaseous products. If the heat is retained, the coal mass will increase in temperature and the oxidation rate will increase, leading to spontaneous combustion $[1 \div 3]$

Research into coal oxidation and its application for the detection and prevention of spontaneous combustion

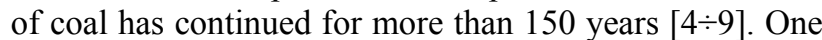
strand of the research work is on the effect of various factors on the oxidation process and characteristics of gaseous products of coal $[10 \div 12]$. The gaseous products, in particular carbon monoxide $(\mathrm{CO})$ and ethene $\left(\mathrm{C}_{2} \mathrm{H}_{4}\right)$, are important indicators to detect the onset and development stages of spontaneous combustion in coal mines $[13 \div 15]$. Coal oxidation and its gaseous products are affected by several factors such as composition and physical properties of coal, temperature, moisture content and partial pressure of $\mathrm{O}_{2}$ in the gas medium [16 $\left.\div 19\right]$.

The atmosphere in underground coal mines often contains methane $\left(\mathrm{CH}_{4}\right)$ and has less $\mathrm{O}_{2}$ concentration than in normal atmospheric air. In-situ measurements indicate that the atmosphere in active goafs can have a wide range of $\mathrm{O}_{2}(0 \div 21 \%)$ and $\mathrm{CH}_{4}\left(0 \div 100 \% \mathrm{CH}_{4}\right)$, and the $\mathrm{CH}_{4}$ concentration in roadways adjacent to goafs can have up to $3 \%[20 \div 22]$. Some field observations suggest that low $\mathrm{CH}_{4}$ concentration in mine atmosphere tends to shorten the incubation period of spontaneous combustion of coal. For example, the incubation period of spontaneous combustion of the $3_{\mathrm{L}}$ coal seam in Tengdong coal mine, Shandong, China, was measured to be between 3 to 6 months in normal air condition and field observation indicated that the incubation period was only 29 days in the goaf with 0,5 to $4 \% \mathrm{CH}_{4}$ concentration.

A number of investigators have observed a dependence of the rate of coal oxidation on oxygen concentration in the gas medium [23], they suggested that the rate of oxygen consumption over a wide range of oxygen concentration can be expressed as a power of the partial pressure of oxygen in the oxidation medium with the exponent varying between zero and unity. However, in these studies no $\mathrm{CH}_{4}$ was present in the gas medium. In fact, there is little published literature available on how coal oxidation and spontaneous combustion are affected by the combined effect of the reduced partial pressure of 
$\mathrm{O}_{2}$ and the existence of low $\mathrm{CH}_{4}$ concentration in mine atmosphere.

$\mathrm{CO}$ is the most commonly used gas indictor in the prediction of coal spontaneous combustion in coal mines as its appearance and production rate indicate the stages of coal spontaneous combustion $[24 \div 26]$. This laboratory study aims to understand the effect of the reduced partial pressure of $\mathrm{O}_{2}(10$ to $21 \%)$ and low $\mathrm{CH}_{4}$ concentration ( 0 $\div 3 \%$ ) in mine atmosphere on coal spontaneous combustion in the temperature range from 30 to $200{ }^{\circ} \mathrm{C}$.

\section{Test method}

The test apparatus consists of a gas mixing system, a temperature control system, a gas analysing system, and a coal sample cylinder, as shown in Figure 1. The apparatus is designed to simulate coal spontaneous combustion under various gas conditions and analyse the gaseous products of spontaneous combustion. The gas mixing system can make gases of any mixture of $\mathrm{O}_{2}, \mathrm{~N}_{2}$ and $\mathrm{CH}_{4}$ and provide steady gas flow to the sample cylinder. The temperature control system can provide controllable temperature environments for coal spontaneous combustion. The gas analysing system is used to analyse the composition of the gaseous products of coal spontaneous combustion.
The gas mixing system consists of an $\mathrm{O}_{2}$ cylinder, a $\mathrm{N}_{2}$ cylinder, a $\mathrm{CH}_{4}$ cylinder, a cylinder for mixed gas, gas pressure regulators, gas pressure stabilisers, gas flow metres, gas flow valves and gas pipelines. A mixed gas of any combination of $\mathrm{O}_{2}, \mathrm{~N}_{2}$ and $\mathrm{CH}_{4}$ concentrations can be obtained by adjusting flow rates from the cylinders of $\mathrm{O}_{2}$, $\mathrm{N}_{2}$ and $\mathrm{CH}_{4}$. The cylinder for mixed gas is connected to the coal sample container and ready for use.

The temperature control system includes an enclosed tank, a temperature sensor and an electric heating unit. The inner and outer layers of the tank use stainless steel and cold-rolling carbon steel respectively and the gap between the layers is filled with high density aluminium silicate fibre for heat in simulation. A Pt100 temperature sensor is installed to monitor the tank temperature and stainless steel heating pipes are used to control the tank temperature. The heating pipe lines are installed at the bottom and on both sides of the tank. The system is designed to control the tank temperature in the range of 0 and $650{ }^{\circ} \mathrm{C}$ and the rate of temperature increase between 1 and $20{ }^{\circ} \mathrm{C} / \mathrm{min}$. The gas analysing system uses a coal mine specific gas chromatography GC-4085B. It can detect $\mathrm{CO}, \mathrm{O}_{2}, \mathrm{~N}_{2}, \mathrm{CO}_{2}, \mathrm{CH}_{4}, \mathrm{C}_{2} \mathrm{H}_{4}, \mathrm{C}_{2} \mathrm{H}_{6}, \mathrm{C}_{2} \mathrm{H}_{2}, \mathrm{C}_{3} \mathrm{H}_{8}$ and $\mathrm{C}_{4} \mathrm{H}_{10}$. It takes about 4 to $8 \mathrm{~min}$ to analyze each sample. The minimum detection limit of $\mathrm{CO}$ is $0,5 \mathrm{ppm}$. A gas drying device is installed on the gas inlet side of the gas chromatography.

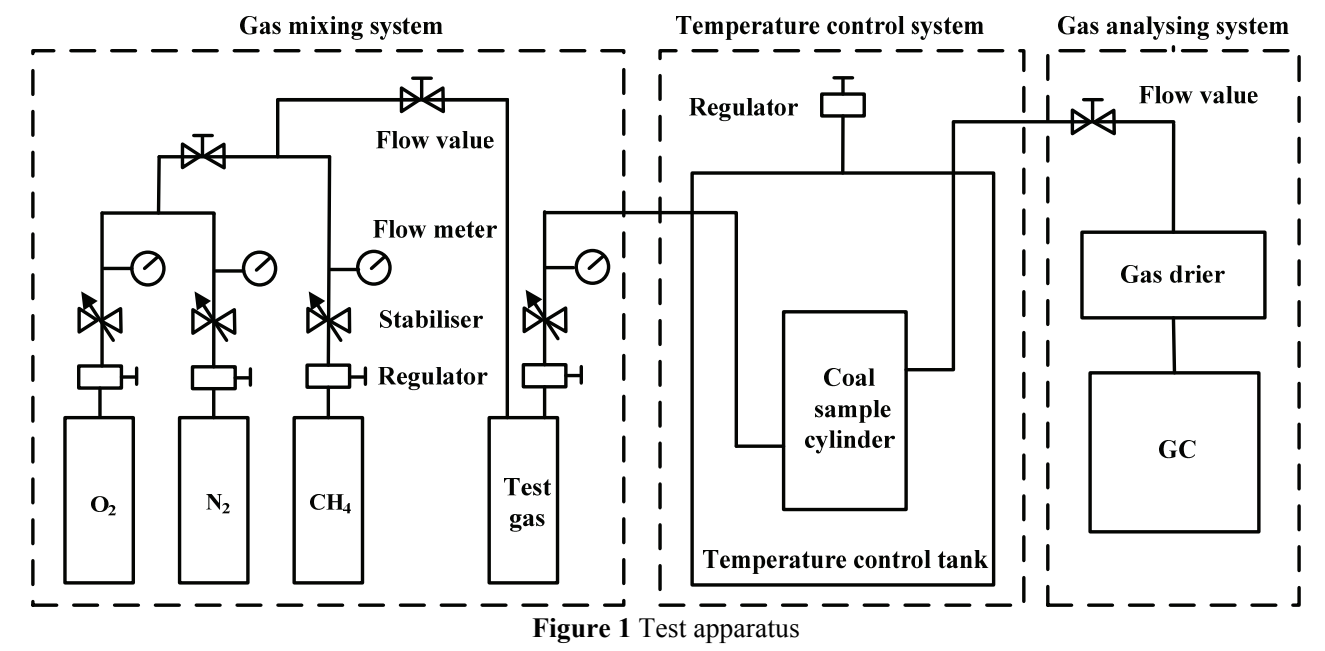

The coal sample cylinder is shown in Fig. 2. The cylinder is $350 \mathrm{~mm}$ high and $100 \mathrm{~mm}$ in diameter. The top of the cylinder is sealed with a sealing cap and the bottom of the cylinder is welded and sealed. The gas inlet is on the left bottom of the cylinder and the gas outlet is on the right top of the cylinder. A layer of meshed copper wires is inserted $80 \mathrm{~mm}$ above the bottom of the cylinder to ensure even distribution of gas inflow and coal sample is placed on the copper wires. A layer of asbestos is covered on the top of coal sample to prevent the gas outlet from blockage. Three temperature sensors are installed inside the cylinder and they are labelled as $1 \#, 2 \#$ and $3 \#$ from the top to bottom of the cylinder. The sensors are located $230 \mathrm{~mm}, 180 \mathrm{~mm}$ and $130 \mathrm{~mm}$ respectively above the bottom of the cylinder.

Bituminous coal was sourced from the $3_{\mathrm{L}}$ coal seam in Tengdong coal mine, Shandong, China. Lumps of coal were taken from a freshly exposed coal face of the mine with a chain saw by removing a layer of coal from the face of $25 \mathrm{~cm}$ thick to avoid the possibility of per oxidation. The coal was sealed in plastic cling wrap upon its retrieval from the face and filled with nitrogen. The coal was then transported to a laboratory in Shandong University of Science Technology, crushed and sieved into samples of particle sizes of 0,18 to $0,38 \mathrm{~mm}$. Its proximate analysis results (air dry basis) show that it contains $1,47 \%$ moisture, 7,58 \% ash, 53,55 \% fixed carbon, $37,4 \%$ volatile matter and $0,45 \%$ total sulphur.

For each test run, the cylinder was loaded with coal sample of $200 \mathrm{~g}$ and put in the temperature control tank. The inlet gas of preset compositions was fed into the cylinder at a steady flow rate of $100 \mathrm{ml} / \mathrm{min}$. The start test temperature was set at $30{ }^{\circ} \mathrm{C}$ which was in line with the in situ temperature of the $3_{\mathrm{L}}$ coal seam. The temperature increase rate was controlled at $1{ }^{\circ} \mathrm{C} / \mathrm{min}$ and the final test temperature was set at $200{ }^{\circ} \mathrm{C}$. The gaseous product at the 
temperature range of 30 to $200{ }^{\circ} \mathrm{C}$ was sampled and analyzed of its $\mathrm{CO}$ concentration with the gas chromatography. The tests were conducted for a total of 12 coal samples in the gas of various compositions of $\mathrm{O}_{2}$, $\mathrm{CH}_{4}$ and $\mathrm{N}_{2}$. Tab. 1 lists the compositions of gas in the tests.

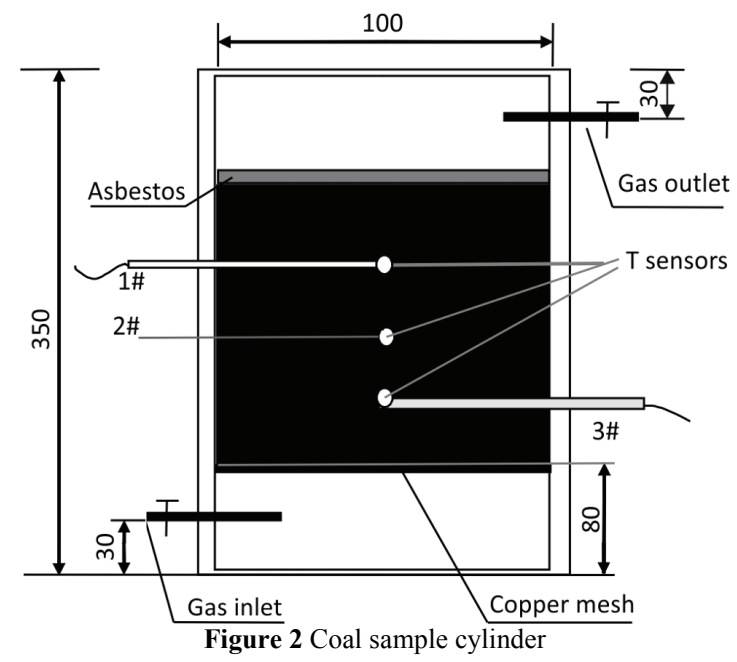

Table 1 The inlet gas compositions

\begin{tabular}{|c|c|c|c|}
\hline Number & $\mathrm{O}_{2} \%$ & $\mathrm{CH}_{4} \%$ & $\mathrm{~N}_{2} \%$ \\
\hline 1 & 10 & 0 & 90 \\
\hline 2 & 10 & 0,82 & 89,18 \\
\hline 3 & 10 & 1,94 & 88,06 \\
\hline 4 & 10 & 3,06 & 86,94 \\
\hline 5 & 15 & 0 & 85 \\
\hline 6 & 15 & 0,82 & 84,18 \\
\hline 7 & 15 & 1,94 & 83,06 \\
\hline 8 & 15 & 3,06 & 81,94 \\
\hline 9 & 21 & 0 & 79 \\
\hline 10 & 21 & 0,82 & 78,18 \\
\hline 11 & 21 & 1,94 & 77,06 \\
\hline 12 & 21 & 3,06 & 75,94 \\
\hline
\end{tabular}

Table $2 \mathrm{CO}$ production (ppm) in gases of $10 \% \mathrm{O}_{2}$ and $0 \div 3,06 \% \mathrm{CH}_{4}$

\begin{tabular}{|c|c|c|c|c|}
\hline $\begin{array}{c}\text { Temperature } \\
{ }^{\circ} \mathrm{C}\end{array}$ & $\begin{array}{c}\mathrm{CH}_{4} \\
0 \%\end{array}$ & $\begin{array}{c}\mathrm{CH}_{4} \\
0.82 \%\end{array}$ & $\begin{array}{c}\mathrm{CH}_{4} \\
\mathrm{CH}_{4}\end{array}$ & $\begin{array}{c}\mathrm{CH}_{4} \\
3.06 \%\end{array}$ \\
\hline 30 & 0 & 0 & 0 & 0 \\
\hline 40 & 0 & 0 & 0 & 0 \\
\hline 50 & 0 & 0 & 2 & 5 \\
\hline 60 & 9 & 11 & 12 & 14 \\
\hline 70 & 23 & 23 & 25 & 31 \\
\hline 80 & 66 & 68 & 59 & 51 \\
\hline 90 & 76 & 82 & 71 & 62 \\
\hline 100 & 106 & 116 & 109 & 93 \\
\hline 110 & 121 & 125 & 114 & 103 \\
\hline 120 & 165 & 176 & 177 & 132 \\
\hline 130 & 461 & 452 & 457 & 426 \\
\hline 140 & 751 & 765 & 745 & 726 \\
\hline 150 & 1156 & 1178 & 1187 & 1125 \\
\hline 160 & 2012 & 1990 & 2063 & 1941 \\
\hline 170 & 2599 & 2639 & 2569 & 2487 \\
\hline 180 & 3289 & 3360 & 3362 & 3218 \\
\hline 190 & 4116 & 4140 & 4095 & 3983 \\
\hline 200 & 5568 & 5600 & 5598 & 5439 \\
\hline
\end{tabular}

\section{Results and discussion}

Tab. 2 lists the CO productions of coal spontaneous combustion in gases containing $10 \% \mathrm{O}_{2}$ and $0 \div 3 \% \mathrm{CH}_{4}$ in the temperature range from 30 to $200{ }^{\circ} \mathrm{C}$. For gases containing $15 \%$ and $21 \% \mathrm{O}_{2}$ the $\mathrm{CO}$ productions were listed in Tabs. 3 and 4 respectively.

Table $3 \mathrm{CO}$ production (ppm) in gases of $15 \% \mathrm{O}_{2}$ and $0 \div 3,06 \% \mathrm{CH}_{4}$

\begin{tabular}{|c|c|c|c|c|}
\hline $\begin{array}{l}\text { Temperature } \\
{ }^{\circ} \mathrm{C}\end{array}$ & $\begin{array}{l}\mathrm{CH}_{4} \\
0 \%\end{array}$ & $\begin{array}{c}\mathrm{CH}_{4} \\
0,82 \%\end{array}$ & $\begin{array}{c}\mathrm{CH}_{4} \\
1,94 \%\end{array}$ & $\begin{array}{c}\mathrm{CH}_{4} \\
3,06 \%\end{array}$ \\
\hline 30 & 0 & 0 & 2 & 6 \\
\hline 35 & 0 & 0 & 5 & 9 \\
\hline 40 & 0 & 3 & 6 & 11 \\
\hline 45 & 5 & 3 & 8 & 9 \\
\hline 50 & 9 & 8 & 11 & 15 \\
\hline 55 & 8 & 11 & 13 & 18 \\
\hline 60 & 11 & 13 & 16 & 22 \\
\hline 65 & 18 & 23 & 22 & 25 \\
\hline 70 & 26 & 29 & 26 & 32 \\
\hline 75 & 29 & 32 & 35 & 38 \\
\hline 80 & 56 & 61 & 58 & 63 \\
\hline 85 & 59 & 67 & 72 & 78 \\
\hline 90 & 72 & 79 & 81 & 88 \\
\hline 95 & 91 & 98 & 89 & 92 \\
\hline 100 & 106 & 113 & 108 & 127 \\
\hline 110 & 125 & 131 & 133 & 146 \\
\hline 120 & 146 & 155 & 159 & 176 \\
\hline 130 & 456 & 507 & 523 & 546 \\
\hline 140 & 646 & 638 & 618 & 668 \\
\hline 150 & 1978 & 2566 & 2437 & 2618 \\
\hline 160 & 6360 & 6669 & 6546 & 6807 \\
\hline 170 & 9139 & 8916 & 8190 & 8286 \\
\hline 180 & 9060 & 9066 & 9280 & 9065 \\
\hline 190 & 8940 & 9328 & 9390 & 9486 \\
\hline 200 & 10606 & 10493 & 10450 & 10562 \\
\hline
\end{tabular}

Table $4 \mathrm{CO}$ production (ppm) in gases of $21 \% \mathrm{O}_{2}$ and $0 \div 3,06 \% \mathrm{CH}_{4}$

\begin{tabular}{|c|c|c|c|c|}
\hline $\begin{array}{c}\text { Temperature } \\
{ }^{\circ} \mathrm{C} \\
\end{array}$ & $\begin{array}{l}\mathrm{CH}_{4} \\
0 \%\end{array}$ & $\begin{array}{c}\mathrm{CH}_{4} \\
0,82 \%\end{array}$ & $\begin{array}{c}\mathrm{CH}_{4} \\
1,94 \%\end{array}$ & $\begin{array}{c}\mathrm{CH}_{4} \\
3,06 \% \\
\end{array}$ \\
\hline 30 & 6 & 5 & 8 & 8 \\
\hline 35 & 8 & 7 & 10 & 10 \\
\hline 40 & 9 & 10 & 12 & 15 \\
\hline 45 & 9 & 16 & 15 & 16 \\
\hline 50 & 14 & 18 & 16 & 18 \\
\hline 55 & 16 & 18 & 22 & 26 \\
\hline 60 & 27 & 22 & 26 & 31 \\
\hline 65 & 28 & 32 & 29 & 38 \\
\hline 70 & 37 & 41 & 51 & 43 \\
\hline 75 & 46 & 52 & 64 & 75 \\
\hline 80 & 73 & 69 & 76 & 83 \\
\hline 85 & 95 & 86 & 92 & 102 \\
\hline 90 & 115 & 108 & 112 & 110 \\
\hline 95 & 128 & 132 & 146 & 152 \\
\hline 100 & 147 & 156 & 169 & 186 \\
\hline 110 & 172 & 185 & 198 & 213 \\
\hline 120 & 213 & 221 & 240 & 268 \\
\hline 130 & 603 & 663 & 750 & 820 \\
\hline 140 & 801 & 931 & 859 & 995 \\
\hline 150 & 2950 & 3067 & 3182 & 3238 \\
\hline 160 & 8978 & 8878 & 8650 & 8853 \\
\hline 170 & 12446 & 12262 & 11385 & 13272 \\
\hline 180 & 15608 & 15952 & 15380 & 15183 \\
\hline 190 & 18152 & 17870 & 18328 & 17954 \\
\hline 200 & 19252 & 19585 & 18992 & 19368 \\
\hline
\end{tabular}

\subsection{The Initial CO Temperature}

The initial $\mathrm{CO}$ temperature is defined as the temperature at which $\mathrm{CO}$ starts to appear in coal 
spontaneous combustion. In this study, the initial $\mathrm{CO}$ temperature and production are extracted from Tabs. 2 to 4 and summarized in Tab. 5. It can be seen from Tab. 5 that the initial $\mathrm{CO}$ temperature and production varied considerably with $\mathrm{O}_{2}$ and $\mathrm{CH}_{4}$ concentrations. In case that no $\mathrm{CH}_{4}$ was present in the gas medium, the initial $\mathrm{CO}$ temperature increased with reduction in $\mathrm{O}_{2}$ concentration. For example, the initial $\mathrm{CO}$ temperature was $30^{\circ} \mathrm{C}$ with $21 \% \mathrm{O}_{2}$ and the temperature increased to $50{ }^{\circ} \mathrm{C}$ and 60 ${ }^{\circ} \mathrm{C}$ as $\mathrm{O}_{2}$ concentration dropped to $15 \%$ and $10 \%$ respectively. In case that low $\mathrm{CH}_{4}$ concentration was present in the gas medium, the initial $\mathrm{CO}$ temperature also increased with reduction in $\mathrm{O}_{2}$ concentration though the increase was somewhat subdued. For example, with increase in $\mathrm{CH}_{4}$ concentration from 0 to $3,06 \%$ the initial $\mathrm{CO}$ temperature dropped from $60{ }^{\circ} \mathrm{C}$ to $50{ }^{\circ} \mathrm{C}$ with $10 \%$ $\mathrm{O}_{2}$ and from $50{ }^{\circ} \mathrm{C}$ to $30{ }^{\circ} \mathrm{C}$ with $15 \% \mathrm{O}_{2}$.

The results indicate that the $\mathrm{O}_{2}$ and $\mathrm{CH}_{4}$ concentrations affect coal spontaneous combustion. The increase in the initial $\mathrm{CO}$ temperature with the reduced $\mathrm{O}_{2}$ concentration indicates that $\mathrm{O}_{2}$ decrease in the gas medium has negative impact on coal spontaneous combustion. The subdued increase in the initial $\mathrm{CO}$ temperature with the presence of the low $\mathrm{CH}_{4}$ concentration indicates that $\mathrm{CH}_{4}$ in the gas medium has a positive impact on coal spontaneous combustion.

Table 5 The initial $\mathrm{CO}$ temperature and production

\begin{tabular}{|c|c|c|c|c|c|c|c|c|}
\hline $\mathrm{O}_{2}$ & \multicolumn{3}{|c|}{$\mathrm{CH}_{4}=0$} & \multicolumn{2}{c|}{$\mathrm{CH}_{4}=0,82 \%$} & \multicolumn{2}{c|}{$\mathrm{CH}_{4}=1,94 \%$} & \multicolumn{2}{c|}{$\mathrm{CH}_{4}=3,06 \%$} \\
\hline$\%$ & $\begin{array}{c}T \\
{ }^{\circ} \mathrm{C}\end{array}$ & $\begin{array}{c}\mathrm{CO} \\
\mathrm{ppm}\end{array}$ & $\begin{array}{c}T \\
{ }^{\circ} \mathrm{C}\end{array}$ & $\begin{array}{c}\mathrm{CO} \\
\mathrm{ppm}\end{array}$ & $\begin{array}{c}T \\
{ }^{\circ} \mathrm{C}\end{array}$ & $\begin{array}{c}\mathrm{CO} \\
\mathrm{ppm}\end{array}$ & $\begin{array}{c}T \\
{ }^{\circ} \mathrm{C}\end{array}$ & $\begin{array}{c}\mathrm{CO} \\
\mathrm{ppm}\end{array}$ \\
\hline 10 & 60 & 9 & 60 & 11 & 50 & 2 & 50 & 5 \\
\hline 15 & 50 & 5 & 40 & 3 & 30 & 2 & 30 & 6 \\
\hline 21 & 30 & 6 & 30 & 5 & 30 & 8 & 30 & 8 \\
\hline
\end{tabular}

\subsection{CO production}

For gases of $10 \% \mathrm{O}_{2}$ and $0 \div 3 \% \mathrm{CH}_{4}$, the $\mathrm{CO}$ production in the temperature range of 30 to $200{ }^{\circ} \mathrm{C}$ is shown in Fig. 3. It can be seen from Fig. 3 that at the same temperature the $\mathrm{CO}$ production had no obvious and consistent variation with the $\mathrm{CH}_{4}$ concentration. For example, at $100{ }^{\circ} \mathrm{C}$ the $\mathrm{CO}$ production was $106,116,109$ and 93 ppm with the $\mathrm{CH}_{4}$ concentration of $0 \%, 0,82 \%$, $1,94 \%$ and $3,06 \%$ respectively. This indicates that the presence of low $\mathrm{CH}_{4}$ concentration in the gas medium of $10 \% \mathrm{O}_{2}$ has no or little influence on the $\mathrm{CO}$ production.

For gases of $15 \% \mathrm{O}_{2}$ and low $\mathrm{CH}_{4}$ concentrations, the $\mathrm{CO}$ production in the temperature range of 30 to $200{ }^{\circ} \mathrm{C}$ is shown in Fig. 4. It can be seen from Fig. 4 that at the same temperature the $\mathrm{CO}$ production generally increased with the $\mathrm{CH}_{4}$ concentration. For example, at $100{ }^{\circ} \mathrm{C}$ the $\mathrm{CO}$ production was $106,113,108$ and 127 ppm with the $\mathrm{CH}_{4}$ concentration of $0 \%, 0,82 \%, 1,94 \%$ and 3,06\% respectively. This indicates that $\mathrm{CH}_{4}$ had a positive impact on $\mathrm{CO}$ production. However, the positive impact gradually diminished with the rise of temperature. For example, at $200{ }^{\circ} \mathrm{C}$ the $\mathrm{CH}_{4}$ concentration showed no or little influence on the $\mathrm{CO}$ production.

For gases of $21 \% \mathrm{O}_{2}$ and low $\mathrm{CH}_{4}$ concentrations, the $\mathrm{CO}$ production in the temperature range of 30 to $200{ }^{\circ} \mathrm{C}$ is shown in Fig. 5. It can be seen from Fig. 5 that at the same temperature the $\mathrm{CO}$ production generally increased with the $\mathrm{CH}_{4}$ concentration. For example at $100{ }^{\circ} \mathrm{C}$ the $\mathrm{CO}$ production was $147 \mathrm{ppm}$ with the gas of zero $\mathrm{CH}_{4}$ concentration and the $\mathrm{CO}$ production increased to 156,169 and $189 \mathrm{ppm}$ as the $\mathrm{CH}_{4}$ concentration rose to $0,82 \%, 1,94 \%$ and $3,06 \%$ respectively. This indicates that $\mathrm{CH}_{4}$ had a positive impact on $\mathrm{CO}$ production. However, the positive impacts lowly diminished with the rise of temperature. For example, at $160{ }^{\circ} \mathrm{C}$ the $\mathrm{CH}_{4}$ concentration had no or little influence on the $\mathrm{CO}$ production.

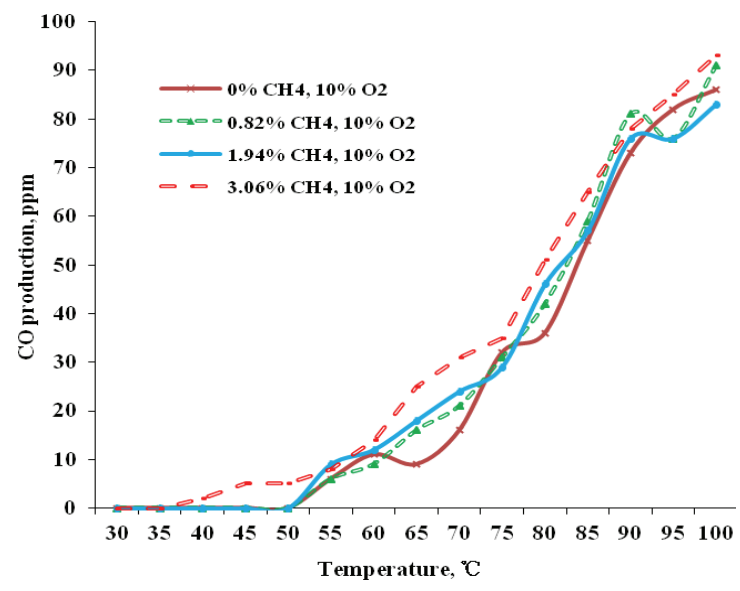

(a) The temperature range 30 to $100^{\circ} \mathrm{C}$

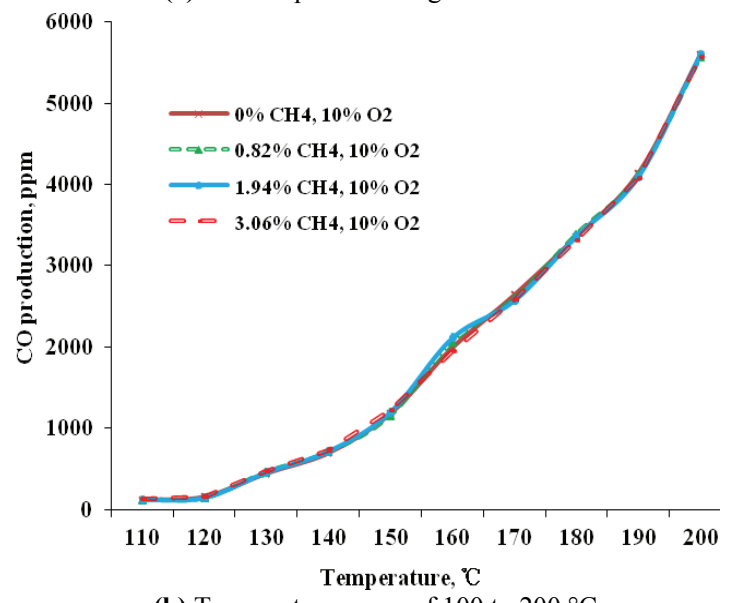

(b) Temperature range of 100 to $200{ }^{\circ} \mathrm{C}$

Figure $3 \mathrm{CO}$ production for gases of $10 \% \mathrm{O}_{2}$ and $0 \div 3 \% \mathrm{CH}_{4}$

A comparison of results in Figs. 3, 4 and 5 shows that at the same temperature and with the low $\mathrm{CH}_{4}$ concentration the $\mathrm{CO}$ production with $21 \% \mathrm{O}_{2}$ was significantly higher than that with $10 \%$ and $15 \% \mathrm{O}_{2}$ and this became more obvious with the rise of temperature. For example at $200{ }^{\circ} \mathrm{C}$ the $\mathrm{CO}$ production with $21 \% \mathrm{O}_{2}$ was $13000 \div 14000 \mathrm{ppm}$ and the $\mathrm{CO}$ production dropped to $8000-9000 \mathrm{ppm}$ with 10 and $15 \% \mathrm{O}_{2}$. This indicates that the $\mathrm{O}_{2}$ concentration in the gas medium had a much more significant effect than the low $\mathrm{CH}_{4}$ concentration on coal spontaneous combustion.

Low temperature spontaneous combustion of coal is a complicated process and has not yet been fully understood. However it is generally accepted that the gaseous products of coal spontaneous combustion in low temperature such as $\mathrm{CO}$ and $\mathrm{CO}_{2}$ are formed through the sorption sequence. The sorption sequence is considered to be the three-step processes, i.e. the chemisorption of $\mathrm{O}_{2}$ on surface of coal pores and formation of unstable 
carbon-oxygen complexes, decomposition of the unstable solid oxygenated intermediates to gaseous products such as $\mathrm{CO}$ and $\mathrm{CO}_{2}$ and stable solid complexes, and the degradation of the stable solid complexes and generation of new active sites for coal spontaneous combustion. As heat is generated mainly from the chemical adsorption of $\mathrm{O}_{2}$ by coal and chemical reaction in coal spontaneous combustion, the $\mathrm{O}_{2}$ concentration in the gas medium is the main reason for the heat accumulation of coal and the subsequent $\mathrm{CO}$ production. The reduction in $\mathrm{O}_{2}$ concentration in the gas medium slows coal spontaneous combustion and $\mathrm{CO}$ production.

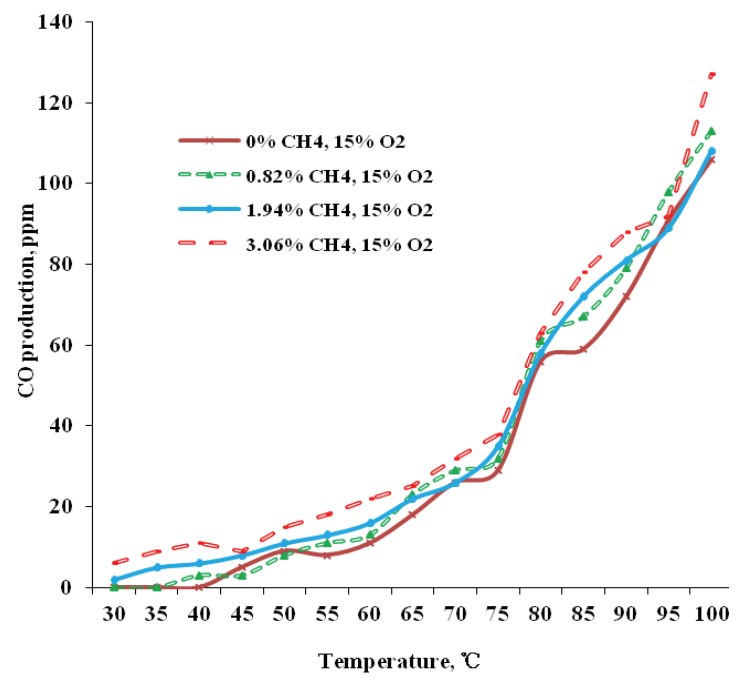

(a) The temperature range 30 to $100{ }^{\circ} \mathrm{C}$

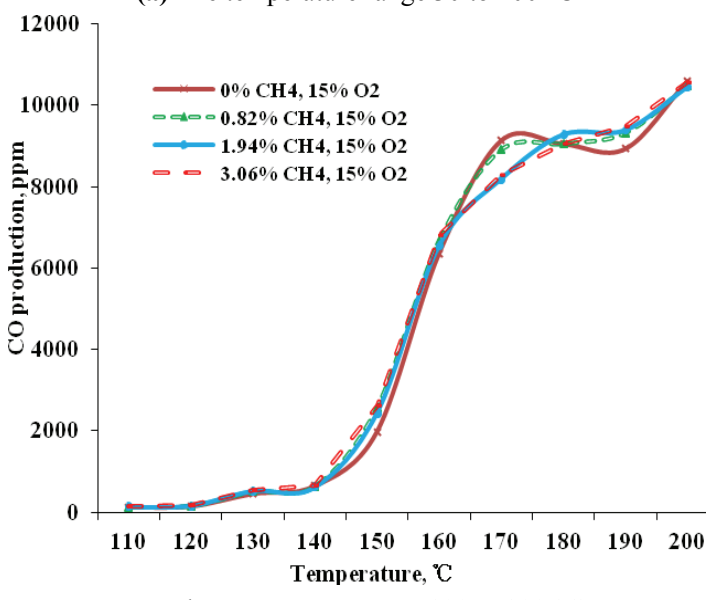

(b) The temperature range 100 to $200{ }^{\circ} \mathrm{C}$

Figure $4 \mathrm{CO}$ production for gases of $15 \% \mathrm{O}_{2}$ and $0 \div 3 \% \mathrm{CH}_{4}$

In case that low $\mathrm{CH}_{4}$ concentration is present in coal spontaneous combustion, as coal has higher geophysical adsorption capability of $\mathrm{CH}_{4}$ than $\mathrm{O}_{2}$ [27], $\mathrm{CH}_{4}$ will occupy part of coal surface through physical adsorption and this will reduce the area of coal surface available for $\mathrm{O}_{2}$ adsorption. The partial occupation of coal surface by $\mathrm{CH}_{4}$ molecules may hinder the dissipation of heat generated through the chemisorptions and chemical reaction between $\mathrm{O}_{2}$ and coal, resulting in more heat accumulation on coal surface and accelerate coal spontaneous combustion. With the rise in temperature, more $\mathrm{CH}_{4}$ desorbs from coal surface and its hindering effect on heat accumulation gradually diminishes and eventually disappears.

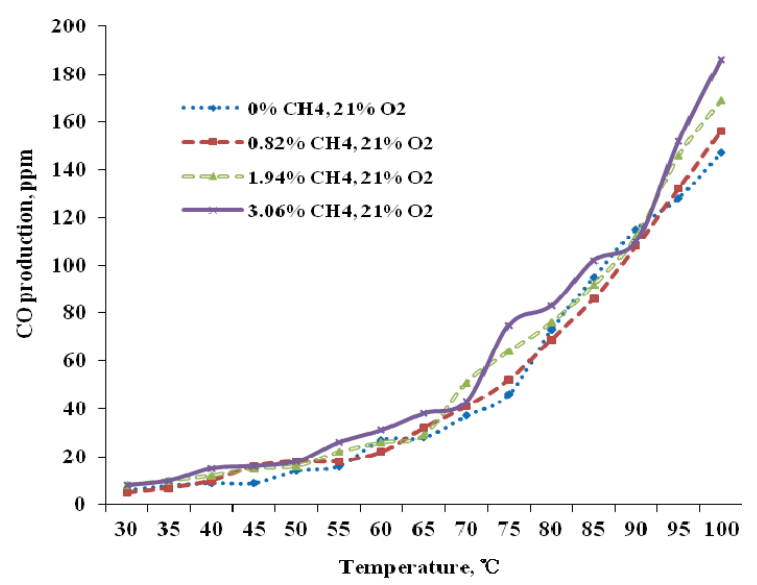

(a) The temperature range 30 to $100{ }^{\circ} \mathrm{C}$

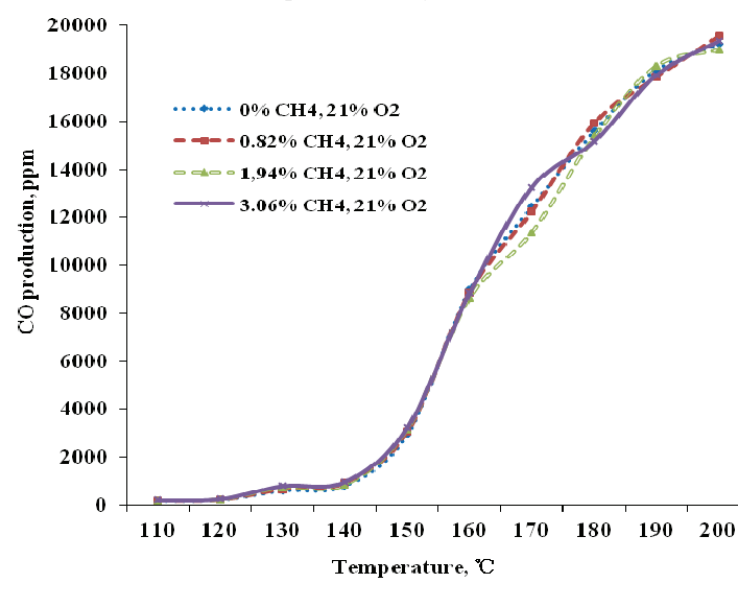

(b) The temperature range 100 to $200{ }^{\circ} \mathrm{C}$

Figure $5 \mathrm{CO}$ production for gases of $21 \% \mathrm{O}_{2}$ and $0 \div 3 \% \mathrm{CH}_{4}$

\section{Conclusion}

This paper presented the test results of lowtemperature spontaneous combustion of coal in the air of $10 \div 21 \% \mathrm{O}_{2}$ and $0 \div 3 \% \mathrm{CH}_{4}$ in an attempt to explain the observed shortened incubation period of coal spontaneous combustion in mine atmosphere. It is concluded that:

(1) Both the initial CO temperature at which CO starts to appear in coal spontaneous combustion and the $\mathrm{CO}$ production at the initial $\mathrm{CO}$ temperature increase with reduction in $\mathrm{O}_{2}$ concentration in air. Reducing $\mathrm{O}_{2}$ concentration in air generates less heat accumulation of coal and slows coal spontaneous combustion.

(2) The presence of low $\mathrm{CH}_{4}$ concentration in air has a positive impact on coal spontaneous combustion. However, the impact gradually diminishes with the rise in temperature. The partial occupation of coal surface by $\mathrm{CH}_{4}$ molecules may hinder the dissipation of heat generated through the chemisorptions and chemical reaction between $\mathrm{O}_{2}$ and coal, resulting in more heat accumulation on coal surface and accelerate coal spontaneous combustion. With the rise in temperature more $\mathrm{CH}_{4}$ molecules desorb from coal surface and its hindering effect on heat accumulation gradually diminishes and disappears.

(3) $\mathrm{O}_{2}$ concentration in air has a more profound effect on coal spontaneous combustion than the presence of low $\mathrm{CH}_{4}$ concentration in air. 


\section{Acknowledgement}

The authors greatly acknowledge the financial supports of National Natural Science Foundation of China (51304128), Specialized Research Fund for the Doctoral Program of Higher Education (20133718120013), Shandong Provincial Natural Science Foundation, China (ZR2013EEQ015), Scientific Research Foundation of Shandong University of Science and Technology for Recruited Talents (2013RCJJ049) and China Postdoctoral Science Foundation (2013M541942).

\section{$5 \quad$ References}

[1] Carras, J. N.; Young, B. C. Self-heating of coal and related materials: model, application and test methods. // Progress in Energy and Combustion Science. 20, 1(1994), pp. 1-15. DOI: 10.1016/0360-1285(94)90004-3

[2] Beamish, B. B.; Blazak, D. G. Relationship between ash content and R70 self-heatingrate of Callide Coal. // International Journal of Coal Geology. 64, 1(2005), pp. 126-132. DOI: 10.1016/j.coal.2005.03.010

[3] Zhang, Y.; Wu, J.; Chang, L.; Wang, J.; Xue, S.; Li, Z. Kinetic and thermodynamic studies on the mechanism of low-temperature oxidation of coal - a case study of Shendong coal (China). // International Journal of Coal Geology. 120, 1(2013), pp. 41-49. DOI: 10.1016/j.coal.2013.09.005

[4] Wang, W. H.; Hou, Y. C.; Niu, M. G.; Wu, T.; Wu, W. Z. Production of benzene polycarboxylic acids from bituminous coal by alkali-oxygen oxidation at high temperatures. // Fuel Processing Technology. 110, (2013), pp. 184-189. DOI: 10.1016/j.fuproc.2012.12.011

[5] Jones, R. E.; Townend, D. T. A. Mechanism of the oxidation of coal. // Nature. 155, (1945), pp. 424-425. DOl: 10.1038/155424b0

[6] Carpenter, D. L.; Giddings, D. G. Initial stages of the oxidation of coal with molecular oxygen i-effect of time temperature + coal rank on rate of oxygen consumption. // Fuel. 43, 4 (1964), pp. 375-383.

[7] Nugroho, Y. S; McIntosh, A. C.; Gibbs, B. M. Lowtemperature oxidation of single and blended coals. // Fuel. 79, 15(2000), pp. 1951-1961. DOI: 10.1016/S00162361(00)00053-3

[8] Wang, H.; Dlugogorski, B. Z.; Kennedy, E. M. Coal oxidation at low temperatures: oxygen consumption, oxidation products, reaction mechanism and kinetic modeling. // Progress in Energy and Combustion Science. 29, 6(2003), pp. 487-513. DOI: 10.1016/S0360-1285(03)00042$\mathrm{X}$

[9] Yang, Y.; Li, Z.; Hou, S.; Gu, F.; Gao, S.; Tang, Y. The shortest period of coal spontaneous combustion on the basis of oxidative heat release intensity. // International Journal of Mining Science and Technology. 24, 1(2014), pp. 99103. DOI: 10.1016/j.jmst.2013.12.017

[10] Arisoy, A.; Basil, B. Mutual effects of pyrite and moisture on coal self-heating rates and reaction rate data for pyrite oxidation. // Fuel. 139 (2015), pp. 107-114. DOl: 10.1016/j.fuel.2014.08.036

[11] Clemens, A. H.; Matheson, T. W. The role of moisture in the self-heating of low-rank coals. // Fuel. 75, 7(1996), pp. 891-895. DOI: 10.1016/0016-2361(96)00010-5

[12] Qi, X.; Wang, D.; James, A. M.; Zhong, X. Self-reaction of initial active groups in coal. // International Journal of Mining Science and Technology. 22, 2(2012), pp. 169-175. DOI: 10.1016/j.jjmst.2011.08.006

[13] Beamish, B. B.; Lau, A. G.; Moodie, A. L.; Vallance, T. A. Assessing the self-heating behaviour of Callide coal using a 2-metre column. // Journal of Loss Prevention in the Process Industries. 15, 5(2001), pp. 385-390. DOI: 10.1016/S0950-4230(02)00020-7

[14] Xie, J.; Xue, S.; Chen, W.; Wang, G. Early detection of spontaneous combustion of coal in underground coal mines with development of an ethylene enriching system. // International Journal of Coal Geology. 85, 1(2011), pp. 123-127. DOI: 10.1016/j.coal.2010.10.007

[15] Yuan, L.; Smith, A. C. $\mathrm{CO}$ and $\mathrm{CO}_{2}$ emissions from spontaneous heating of coal under different ventilation rates. // International Journal of Coal Geology. 88, 1(2011), pp. 24-30. DOI: 10.1016/j.coal.2011.07.004

[16] Zhang, Y. L.; Wang, J. F.; Wu, J. M.; Xue, S.; Zheng, F. L.; Chang, L. P. Modes and kinetics of $\mathrm{CO}_{2}$ and $\mathrm{CO}$ production from low-temperature oxidation of coal. // International Journal of Coal Geology. 140, (2015), pp. 1-8. DOI: 10.1016/j.coal.2015.01.001

[17] Wang, H.; Dlugogorski, B. Z.; Kennedy, E. M. Analysis of the mechanism of the low-temperature oxidation of coal. // Combustion and Flame. 134, 1-2(2003), pp. 107-117. DOI: 10.1016/s0010-2180(03)00086-5

[18] Carras, J. N.; Day, S. J.; Saghafi, A.; Williams, D. J. Greenhouse gas emissions fromlow-temperature oxidation and spontaneous combustion at open-cut coal mines in Australia. // International Journal of Coal Geology. 78, 2(2009), pp. 161-168. DOI: 10.1016/j.coal.2008.12.001

[19] Baris, K.; Kizgut, S.; Didari, V. Low-temperature oxidation of some Turkish coals. // Fuel. 93, 1(2012), pp. 423-432. DOI: 10.1016/j.fuel.2011.08.066

[20] Lunarzewski, L. Gas emission prediction and recovery in underground coal mines. // International Journal of Coal Geology. 35, 1-4(1998), pp. 117-145. DOI: 10.1016/s01665162(97)00007-4

[21] Karacan, C. O. Reconciling longwall gob gas reservoirs an venthole production performance using multiple rate drawdown well test analysis. // International Journal of Coal Geology. 80, 3-4(2009), pp. 181-195. DOI: 10.1016/j.coal.2009.09.006

[22] Pan, R.; Cheng, Y.; Yu, M.; Lu, C.; Yang, K. New technological partition for "three zones" spontaneous coal combustion in goaf. // International Journal of Mining Science and Technology. 23, 4(2013), pp. 489-493. DOI: 10.1016/j.jjmst.2013.07.005

[23] Schmidt, L. D.; Elder, J. L. Atmospheric oxidation of coal at moderate temperature: rates of the oxidation for representative coking coals. // Industrial and Engineering Chemistry. 32, 2(1940), pp. 249-256. DOl: 10.1021/ie50362a021

[24] Pone, J. D. N.; Hein, K. A. A.; Stracher, G. B.; Annegarn, H. J.; Finkelman, R. B.; Blake, D. R.; McCormack, J. K.; Schroeder, P. The spontaneous combustion of coal and its byproductsin the Witbank and Sasolburg coalfields of South Africa. // International Journal of Coal Geology. 72, 2(2007), pp. 124-140. DOI: 10.1016/j.coal.2007.01.001

[25] Singh, A. K.; Singh, R. V. K.; Singh, M. P.; Chandra, H.; Shukla, H.K. Mine fire gas indices and their application to Indian undergroundcoal mine fires. // International Journal of Coal Geology. 69, 3(2007), pp. 192-204. DOI: 10.1016/j.coal.2006.04.004

[26] Qin, B.; Lu, Y.; Jia, Y. CO emission in the air return corner of the working face in shallow burialmining areas. // International Journal of Mining Science and Technology. 24, 5(2014), pp. 617-623. DOI: 10.1016/j.jmst.2014.03.026

[27] Wang, L.; Jiang, S.; Wu, Z. Experimental research on effects of $\mathrm{CO}_{2}$ on oxygen physisorption process of coal at low temperature. // Mining Express. 466, 2(2008), pp. 2931. 


\section{Authors' addresses}

Gang Wang, Ph.D., Associate Professor

Laboratory of Mine Disaster Prevention and Control,

Shandong University of Science \& Technology,

Room 427, College of Mining and Safety Engineering, 579

Qianwangang Road Economic \& Technical Development Zone,

Qingdao Shandong Province, 266590 P. R. China

E-mail: Gang.Wang@sdust.edu.cn

Jun Xie, Ph.D., Professor (Corresponding author)

State Key Laboratory Breeding Base for Mining Disaster

Prevention and Control,

Shandong University of Science \& Technology,

Room 431, College of Mining and Safety Engineering, 579

Qianwangang Road Economic \& Technical Development Zone,

Qingdao Shandong Province, 266590 P. R. China

E-mail: mrxie998@sina.com

Sheng Xue, Ph.D.

CSIRO Energy Flagship,

PO Box 883, Kenmore, QLD 4069, Australia.

E-mail: sheng.xue@csiro.au

Haiyang Wang, Ph.D.

State Key Laboratory Breeding Base for Mining Disaster

Prevention and Control,

Shandong University of Science \& Technology,

Room 224, College of Mining and Safety Engineering, 579

Qianwangang Road Economic \& Technical Development Zone,

Qingdao Shandong Province, 266590 P. R. China

E-mail: wanghaiyang12@yeah.net 